Research Article

\title{
Study on Seasonal Prevalence of Helminths in Cyprinus carpio from Chilya Fish Hatchery, Thatta, Sindh, Pakistan
}

\author{
Raheela Noor Memon $^{1 *}$, Nadir Ali Birmani ${ }^{1}$, Naeem Tariq Narejo ${ }^{2}$ and Shahnaz Rashid ${ }^{3}$ \\ ${ }^{1}$ Department of Zoology, University of Sindh, Jamshoro, Pakistan; ${ }^{2}$ Department of Freshwater Biology and Fisheries, \\ University of Sindh, Jamshoro, Pakistan; ${ }^{3}$ Center of Excellence in Marine Biology, University of Karachi, Pakistan.
}

\begin{abstract}
This study was conducted to assess the prevalence of helminth parasites in Cyprinuscarpioat Chilya, Fish Hatchery, Thatta, Sindh from February 2019 to January 2020. A total of 107 samples of Cyprinuscarpio were tested during the research and helminths were found in 17 out of 107 . Various helminths groups were identified including trematode and acanthocephalan. Other helminths groups, such as cestodes and nematodes were not noted. These helminths infected the gut of Cyprinuscarpio including trematode and acanthocephalan. No additional organs were found to be infected with helminths parasites. Helminths prevalence were documented as 41\% in September, 40\% in August, 36\% in October, 33\% in June, September (30.76\%) and April (25\%). During September and October, the helminthes were most abundant, with no infections documented in January, February, March, July, November, or December. Helminths were found in this study throughout specific months of the year.

Received | August 20, 2021; Accepted | September 23, 2021; Published | December 01, 2021

*Correspondence | Raheela Noor Memon, Department of Zoology, University of Sindh, Jamshoro, Pakistan; Email: rahila.sajjad123@gmail.com Citation | Memon, R.N., N.A. Birmani, N.T. Narejo and S. Rashid. 2022. Study on seasonal prevalence of helminths in Cyprinus carpio from chilya Fish hatchery, Thatta, Sindh, Pakistan. Sarbad Journal of Agriculture, 38(1): 195-198.

DOI | https://dx.doi.org/10.17582/journal.sja/2022/38.1.195.198

Keywords | Helminths, Cyprinus carpio, Chilya Fish Hatchery, Thatta, Pakistan
\end{abstract}

\section{Introduction}

C yprinus carpio locally known as Gulfam and uniAversally called as (Common carp) characterized by large, shiny scales. This species is strongly recommended for domestic culture due to omnivorous habit and because of the fact that its entire varieties breed freely all the year round in confined waters (Mirza, 1982). The presence of ectoparasites, is too large extends detrimental for a fish population and consequently, imposes high losses (Fatima and Bilqees, 1989). Parasitic invasion on fish may cause high mortality, weight losses and reduced fecundity. Crustacean parasites caused serious disease on both cultured and wild fish species These parasitic groups hampered fish growth, prevent feeding activity, especially in water contaminated with industrial and urban pollutants, poor water quality caused parasitic disease outbreak.
Losses resulting from these parasites under crowded and uncultured conditions can reach catastrophic proportions. The fishes have been reported to be infected by various types of parasites. Bilqees (1971, $1974,1976)$ have studied the larval nematode in some carp fishes and trematodes infections. As mentioned above in Pakistan sufficient literature is available on the various parasites infecting the fish.

A considerable portion of Pakistan's population is malnourished, owing to insufficient supplies and rising prices for high-quality foods, particularly animal protein. White and red meat are in high demand. Fish meat is nutritionally better in both quality and quantity. Helminthic infections in fish reduce the nutritional content of the fish and result in death (Ahmed, 1994). Fish can be infected by a variety of helminths, comprising trematodes, cestodes, nematodes, and 
acanthocephalans, and their hosts might serve as transitional hosts for certain helminthes (Schmidt, Khan, 1976). The environment for fish requisite bepreserved. To avert mass fish death and protect fisheries sectors, a healthy and parasitic evaluation was carriedout (Ahmed et al., 2007). Helminthic infestation has been shown to cause death, weight loss, and fecundity in fish hosts. Huge losses have been observed as a result of overcrowding and lack of culture. There are infrequent occurrences of helminthic infestation in Sindh's freshwater fish species. A research findings indicate the effort of Abro et al. (2020), Khan (1985), Naqvi et al. (2009) and Rizvi (1974). These experiments were carried out on wild fish. As a result, a study on endoparasites of Cyprinuscarpio from the fish hatchery Chilya Thatta was planned.

\section{Materials and Methods}

A total of 107 samples of fresh water fish, Cyprinuscarpio were collected from Chilya, Hatchery, and Thatta. The host was taken to the University of Sindh's Z $\mathrm{O}^{-}$ ology Department for an endoparasite examination. The parasite was found in all organs of the host fish when it was dissected. In petri dishes containing ordinary saline solution, organs are isolated and teased. The content was inspected using an Amscope Led Trinocular Zoom Steromicroscope. The parasite was examined for identification and processed according to the procedure described in Schmidt (1988).

\section{Results and Discussion}

During the assessment of 107 samples of Cyprinuscarpio, it was discovered that 17 of them were infested with helminths. Helminths with zero infections reported in January, February, March, July, November, or Decemberwhile infections were most common in September and October, (Table 1). Parasite frequency is revealed $41 \%$ in September, $40 \%$ in August, $36 \%$ in October, $33.3 \%$ in June, $30.76 \%$ in September, and 41\% in April 25\%. Cyprinuscarpio was examined for endoparasites occurrence from February 2019 to November 2020 in this study. Late summer had the highest incidence, whereas early summer had the lowest. Fatima and Bilquees (1989) evaluated the seasonal fluctuation and degree of parasite infection on various edible fish hatcheries in Thatta. In September, they discovered that $41 \%$ of the fish were infested with endoparasites. Linton (1914) observed Seasonal fluctuation in parasite intensity was detect- ed in a variety of freshwater fishes. He also revealed that the occurrence of fish helminths had a regular pattern. Several researchers, counting (Akhter et al.,1997; Banu et al., 1993; Hussain et al., 1994). In Bangladesh, a parasitic illness was discovered during the winter season. Milbrink (1975) reported a significant parasite infestation in the spring, From February through November, according to Reimchain (1982) there is the largest prevalence of parasite infection. In a study conducted by Koc et al. (2018), 4.88 percent of C. Carpio as well as other fishes were found to be infested with helminths.

Table 1: Fish samples examined for the presence of helminth parasites.

\begin{tabular}{|c|c|c|c|c|}
\hline Month & $\begin{array}{l}\text { Number of } \\
\text { fish samples } \\
\text { examined }\end{array}$ & $\begin{array}{l}\text { Number of } \\
\text { fish samples } \\
\text { found positive }\end{array}$ & $\begin{array}{l}\text { Number of } \\
\text { helminths } \\
\text { recovered }\end{array}$ & $\begin{array}{l}\text { Per- } \\
\text { centage }\end{array}$ \\
\hline $\begin{array}{l}\text { February, } \\
2019\end{array}$ & 12 & Nil & Nil & Nil \\
\hline March & 05 & Nil & Nil & Nil \\
\hline April & 08 & 02 & 06 & $25 \%$ \\
\hline June & 06 & 02 & 10 & $33.3 \%$ \\
\hline July & 10 & Nil & Nil & Nil \\
\hline August & 10 & 04 & 11 & $40 \%$ \\
\hline September & 12 & 05 & 17 & $41 \%$ \\
\hline October & 11 & 04 & 15 & $36 \%$ \\
\hline November & 10 & Nil & Nil & Nil \\
\hline December & 12 & Nil & Nil & Nil \\
\hline $\begin{array}{l}\text { January, } \\
2020\end{array}$ & 11 & Nil & Nil & Nil \\
\hline
\end{tabular}

\section{Conclusions and Recommendations}

Helminths were found in this study throughout specific months of the year. During September and October, the helminthes were most abundant, with no infections documented in January, February, March, July, November, or December. The current research adds to the body of knowledge about parasite incidence in freshwater fish species in Sindh province, with a focus on the Cyprinus carpio and the carp fish hatchery in Thatta, Sindh, Pakistan.

\section{Acknowledgments}

This research is a part of the Ph.D thesis of first author (Raheela Noor Memon). The Principal author is thankful to Chairperson, Department of Zoology, University of Sindh for providing lab facilities. 


\section{Novelty Statement}

Outcomes of present work will be advantageous to fisheries sector through basic knowledge of seasonal prevalence of helminths in CyprinusCarpio from Chilya Fish Hatchery, Thatta, Sindh, Pakistan so as no previous literature was found on this work in $\mathrm{Pa}^{-}$ kistan.

\section{Author's Contribution}

Raheela Noor Memon: Designed and conducted this research as part of the $\mathrm{PhD}$ thesis.

Nadir Ali Birmani: Supervised the research helped in manuscript preparation.

Naeem Tariq Narejo: Provided technical guidelines

Shahnaz Rashid: Helped in composing, formatting and updating bibliography.

\section{Conflict of interest}

The authors have declared no conflict of interest.

\section{References}

Abro, M.M., Birmani, N.A. Brohi, G.H. and Rajper, M. 2020. Detection of a pathogenic nematode from tire track eel, Mastacembelusarmatus captured in the Indus River, Sindh, Pakistan. Pure Appl. Biol., 9(1): 963-967. https://doi. org/10.19045/bspab.2020.90101

Ahmed, M.S. 1994. Trypanosomiasis in common carp, Cyprinuscarpio L., Ph.D. Thesis, Zoological Institute, Catholic University Leuven, Belgium. Pp. 12.

Ahmed, M.S. Iqbal, T. Mahmood, A. Gulzarin, M. and Abid, M. 2007. Helminth parasites of some freshwater fishes. Punjab Univ. J. Zool., 22 (12): 01-06.

Akhter, M., D Silva, J. and Khanum, A. 1997. Helminth parasites of Anabas testdineus (Bloch) in Bangladesh. Bang. J. of Zool., 25: 135- 138.

Banu, A.N.H., Hossain, M.A. and Khan, M.H., 1993. Investigation into the occurrence of parasites in carps, catfish and tilapia. Prog. Agric. 4: 11-19.

Bilqees, F.M. 1971. Parasites of the cat fish Arius serralus. I. Acanthocephala. Pak. J. of Zool., 3: 57-65.

Bilqees, F.M. 1974. Morphological variations in
Bianiumplicitum (Linton, 1928) Stunkard, 1930 (Trematoda) from a fish of the Karachi coast. Acta Parasitol. Pol., 22: 305-310.

Bilqees, F.M. 1976. Two new lepocreadiidtrematodes from fishes of the Karachi coast. Norway J. Zool., 24: 195-199.

Bilqees, F.M. 1986. Digenetic trematodes of freshwater fishes of Pakistan. Proc. Parasitol., 2: 74108.

Fatima, H. and Bilqees, F.M. 1989. Seasonal variation of nematodes and acanthocephalan of some fishes of Karachi coast. Proc. Parasitol., 7:8: 1-20.

Ghazi, R.R. and Ataur-Rahim. 1999. Proposal for a new species Rhabdochonamegasacculata (Nematoda: Rhabdochonidae) from a freshwater fish Briliusvagra (Ham. 1889) caught from the Chattar Stream, Islamabad. Proc. Parasitol., 28:61-65.

Hussain, M., Banu, A.N.H. and Khan, M.H. 1994. Prevalence of ectoparasite in carp nursery operation of greater Mymensingh. Prog. Agric., 5: 39- 44.

Khan, A. 1985. Phyllodistomumritai new species (Trematoda: Gorgoderidae: Phyllodistominae) from a freshwater fish of Kalri lake, Sindh, $\mathrm{Pa}-$ kistan. Proc. Parasitol., 1:1-5.

Koc, C., Aldemir O.S. and Selamoglu Z. 2018. Helminth parasites of sea bass (Dicentrarchus labrax, Linnaeus, 1758), gray mullet (Chelonl abrosus, Aisso, 1826) from Bafa Lake, Turkey. J. Surv. Fish. Sci., 5(1): 1-6. https://doi. org/10.18331/SFS2018.5.1.1

Milbrink, G. 1975. Population biology of the cestode Caryophyllaeus laticeps (Pallas) in bream, Arabins brana (L.) and the feeding of fish on Oligochaetes. Rep. Hist. Freshw. Res. Drotlningholm, 54: 36-51

Mirza, M.R. 1982. A contribution to the fishes of Lahore. Polymer Publications Urdu Bazaar, Lahore. pp. 48.

Naqvi, S.M.H.M., Ghazi, R.R. and Khan, A. 2009. A new trematode of the family Leprocreadiidae (Odhner, 1905) Nicoll, 1935 from a freshwater fish of Sindh, Pakistan. Proc. Parasitol., 47:7578.

Reimchen, T.E. 1982. Incidence and intensity of Cyathocephalus solidus infection in Gasterosteusaculeatus. Canad. J. Zool., 60: 1091-1095.

Rizvi, S.S.H. 1974. Monogenea of Pakistani fishes, IV. Survey of the monogenetic trematodes in 
fishes of river Indus and its canals. Agric. Pak., 25 (2): 113-118.

Schmidt, G.D., H.D. Walley and D.S. Wijek. 1974. Unusual pathology in a fish due to the acanthocephalan Acanthocephalus jacksoni Bullock, 1962. J. Parasitol., 60(4): 730-731.

Schmidt, G.D. 1988. Essentials of Parasitology 4th Edition. Wm. C. Brown Publishers 2460 Keper Boulevard, Dubuque, IA 52001. pp. 294.

Shaikh, G.S. and Bilqees, F.M. 2008. Plagioporussindhen.sp. (Trematoda: Opecoelidae) from freshwater fish Labeorobita, Keenjhar lake, Thatta, Sindh. Proc. Parasitol., 46:73-85.

Soofi, H., Birmani, N.A. and Bhutto, A. 2016. New species of genus Sphincterostoma Yamaguti, 1937 reported from Bagridae (Bleeker, 1858) catfish Rita rita ( Siluriformes: Bagridae) of River Indus at District Jamshoro, Sindh, Pakistan. Int. J. Adv. Res., 4(9): 1358-1362. https://doi. org/10.21474/IJAR01/1734

Soofi, H., Birmani, N.A. and Dharejo, A.M. 2016. Dendrorchisritatan. sp. (Trematoda: Gorgoderidae) from catfish Rita rita (Siluriformes: Bagridae) of Jamshoro district, Sindh, Pakistan. Int. J. Fauna Biol. Stud., 3(3): 17-19.

Soofi, H., Birmani, N.A. and Dharejo, A.M. 2016. Thaparotremashamiminew species in catfish Rita rita(Hamilton, 1822) from Jamshoro district Sindh, Pakistan. Int. J. Adv. Res. Biol. Sci., 3(9): 124-129. https://doi.org/10.22192/ ijarbs.2016.03.09.018

Soofi, H., Birmani, N.A. and Dharejo, A.M. 2016. The first record of (Nematoda: Camallanidae) genus Onchocamallanus Petter, 1979 from Sindh province of Pakistan. J. Entomol. Zool. Stud., 4(5):851-853.

Soofi, H., Birmani, N.A. and Dharejo, A.M. 2017. Rhabdochonaindusi new species (Nematoda: Rhabdochonidae) in Rita rita(Siluriformes: Bagridae) from Sindh, Pakistan. J. Biodivers. Environ. Sci., 10(2): 220-230.

Soofi, H., Birmani, N.A. and Dharejo, A.M. 2017.
The first record of genus Pseudophyllodistomum Cribb, 1987 from Siluriform catfish Mystuscavasius (Hamilton, 1822) of River Indus Sindh, Pakistan. J. Entomol. Zool. Stud., 5(1): 209211.

Soofi, H., Birmani, N.A. and Dharejo, A.M. 2018. Genus Falccautra Lane, 1915 recorded from new host Catfish Wallago attu (Siluriformes: Siluridae) of district Jamshoro, Sindh, Pakistan. FUUAST J. Biol., 8(1): 9-14.

Soofi, H., Birmani, N.A., Dharejo, A.M. and Bhutto, A. 2016. Description of new species Witenbergiamystusi of genus Witenbergia Vaz, 1932 from River Indus catfish Mystuscavasius (Hamilton, 1822) Sindh, Pakistan. Int. J. Innov. Appl. Res., 4(9): 21-25.

Soofi, H., Birmani, N.A., Dharejo, A.M. and Abbasi, A.R. 2015. First record of genus Thaparotrema Gupta, 1955 (Trematoda: Ophisthorchiidae) in Pakistan. J. Entomol. Zool. Stud., 3(6): 232-234.

Soofi, H., Birmani, N.A., Dharejo, A.M. and Abbasi, A.R. 2018. New host and locality record of Comephoronemamultipapillatumfrom Wallago attu of Indus River Jamshoro, Sindh, Pakistan. Sci. Int., 30(4): 601-605.

Soofi, H., Birmani, N.A., Dharejo, A.M., Abbasi, A.R. and Ghachal, G.S. 2021. Thaparotremaakbari new species of genus Thaparotrema Gupta, 1955 from host Rita rita(Siluriformes: Bagridae) of River Indus Sindh Pakistan. Pure App. Biol., 10(1): 254-261. https://doi.org/10.19045/bspab.2021.100026

Soofi, H., Birmani, N.A., Dharejo, A.M., Abbasi, A.R. and Ghachal, G.S. 2020. Description of new nematode species Rhabdochona (Rhabdochona) sindhicus of genus Rhabdochona (Railliet, 1916) from Indus River Pakistan. Pak. J. Nemat., 38(1): 81-91. https://doi.org/10.18681/ pjn.v38.i01.p81-91

Zaidi, D.A. and Khan, D. 1976. Cestodes of fishes from Pakistan. Biol. (Lahore)., 22: 157-179. 